\title{
Rofecoxib-induced hepatotoxicity: A forgotten complication of the coxibs
}

\author{
Brian Yan $M D^{1}$, Yvette Leung $M D^{1}$, Stefan J Urbanski $M D^{2}$, Robert P Myers $M D^{1}$
}

\begin{abstract}
B Yan, Y Leung, SJ Urbanski, RP Myers. Rofecoxib-induced hepatotoxicity: A forgotten complication of the coxibs. Can J Gastroenterol 2006;20(5):351-355.

Rofecoxib is a member of the coxib family of nonsteroidal antiinflammatory drugs that selectively inhibit cyclooxygenase-2. Although the coxibs are generally well-tolerated, rofecoxib was recently withdrawn from the market due to concerns regarding cardiovascular safety. Rare cases of hepatic injury attributable to the coxibs have been reported. In the present study, two additional cases of severe hepatotoxicity are described in patients with cholestatic symptoms and abnormal liver biochemistry, shortly following the initiation of rofecoxib for arthritic complaints. In both cases, liver histology was compatible with drug-induced hepatotoxicity, and rapid clinical and biochemical improvements were observed following rofecoxib discontinuation. With new coxibs and expanding indications on the horizon, physicians in all areas of practice must be aware of this disorder and consider it in any patient who develops hepatic dysfunction after taking a coxib.
\end{abstract}

Key Words: Adverse effects; Cholestasis; Coxib; Drug toxicity; Hepatitis; Rofecoxib

\section{L'hépatotoxicité du rofécoxib : complication oubliée des coxibs}

Le rofécoxib fait partie de la famille des coxibs, anti-inflammatoires non stéroïdiens qui entravent de façon sélective la cyclo-oxygénase-2. Même si les coxibs se tolèrent généralement bien, le rofécoxib a été retiré dernièrement du marché pour des raisons de nocuité cardiovasculaire. De rares cas d'atteinte hépatique, attribuable aux coxibs ont déjà été signalés. La présente étude fait état de deux autres cas d'hépatotoxicité grave, se traduisant par des symptômes cholestatiques et des analyses biochimiques anormales du foie peu après l'amorce d'un traitement au rofécoxib pour des douleurs arthritiques. Dans les deux cas, l'examen histologique du foie était compatible avec une réaction hépatotoxique d'origine médicamenteuse, et l'arrêt du traitement au rofécoxib a été suivi rapidement d'une amélioration clinique et biochimique. Compte tenu de l'arrivée de nouveaux coxibs et de la reconnaissance possible de nouvelles indications, les médecins, quel que soit leur champ de pratique, devraient être sensibilisés à l'apparition de cette réaction, et celle-ci devrait être envisagée chez tous les patients qui présentent des troubles hépatiques après la prise d'un coxib.
T he coxibs are a class of nonsteroidal anti-inflammatory drugs (NSAIDs) designed to selectively inhibit cyclooxygenase-2 (COX-2) (1). They have gained widespread popularity as analgesics, based on their improved gastrointestinal safety profile compared with nonselective NSAIDs $(2,3)$. However, the cardiovascular safety of the coxibs has come under scrutiny. Due to an increased risk of myocardial infarction and stroke in the Adenomatous Polyp Prevention on Vioxx (APPROVE) study, rofecoxib (Vioxx, Merck and Co Inc, Canada) was recently withdrawn by the manufacturer $(4,5)$. For similar reasons, sales of valdecoxib (Bextra, Pfizer Canada Inc) were recently suspended, but celecoxib (Celebrex, Pfizer Canada Inc) remains on the North American market.

Significant hepatotoxicity due to NSAIDs, including the coxibs, is uncommon. The estimated annual incidence is one to 10 cases per 100,000 exposed individuals (6,7). In the Celecoxib Long-term Arthritis Safety Study (CLASS), 0.6\% of celecoxibtreated patients experienced an alanine aminotransferase (ALT) elevation; only $0.2 \%$ had an elevation greater than three times the upper limit of normal (3). In the present report, we describe two cases of severe rofecoxib-induced hepatic injury with the intention of highlighting this potentially serious complication of the coxibs.

\section{CASE PRESENTATIONS}

\section{Case 1}

A 44-year-old Caucasian man presented with a four-day history of painless jaundice, nausea and malaise two weeks after beginning rofecoxib $25 \mathrm{mg}$ daily for osteoarthritis of the knees. The patient had taken rofecoxib on several occasions over the preceding three years, but only for a few days at a time. The patient's past medical history included noninsulin-dependent diabetes mellitus, psoriasis and a cutaneous follicular lymphoma of the cheek resected six months before presentation. Longstanding medications included insulin and a corticosteroid ointment for psoriasis. The patient denied other recent changes in his medications, ingestion of potential hepatotoxins, significant alcohol consumption or allergies. There were no risk factors for viral hepatitis or a family history of liver disease.

On examination, the patient was markedly jaundiced; however, there was no sign of chronic liver disease or organomegaly. The patient was afebrile and there was no lymphadenopathy or cutaneous recurrence of lymphoma. Laboratory investigations revealed a normal blood count (including absence of eosinophilia), ALT $1826 \mathrm{U} / \mathrm{L}$ (normal less than $60 \mathrm{U} / \mathrm{L}$ ), alkaline phosphatase (ALP) $741 \mathrm{U} / \mathrm{L}$ (normal less than $145 \mathrm{U} / \mathrm{L}$ ), gamma-glutamyltransferase $897 \mathrm{U} / \mathrm{L}$ (normal less than $60 \mathrm{U} / \mathrm{L}$ ),

${ }^{1}$ Liver Unit, Division of Gastroenterology, Department of Medicine; ${ }^{2}$ Department of Pathology, University of Calgary; Calgary, Alberta

Correspondence: Dr Robert P Myers, G126, 3330 Hospital Drive North West, Calgary, Alberta T2N 4N1. Telephone 403-210-9837,

fax 403-210-9368, e-mail rpmyers@ucalgary.ca

Received for publication May 1, 2005. Accepted January 9, 2006 


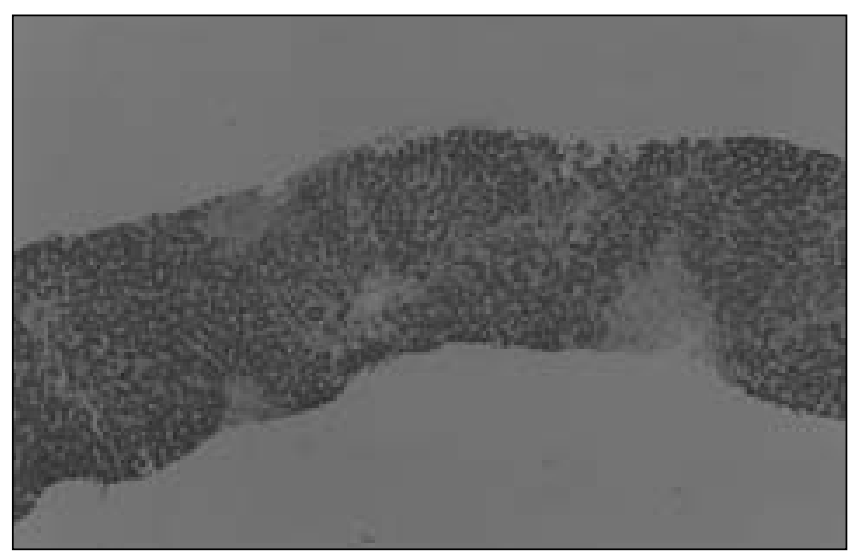

Figure 1) Expansion of the periportal and perivenular spaces due to inflammation with focal hepatocellular necrosis (periodic acid-Schiff stain, original magnification $\times 100$ )

total bilirubin $242 \mu \mathrm{mol} / \mathrm{L}$ (normal less than $17 \mu \mathrm{mol} / \mathrm{L}$ ), albumin $30 \mathrm{~g} / \mathrm{L}$ and an international normalized ratio of 1.1. Serum bile acids were markedly elevated $(279 \mu \mathrm{mol} / \mathrm{L}$; normal less than $8.2 \mu \mathrm{mol} / \mathrm{L}$ ). Antinuclear (ANA) and smooth muscle antibodies, as well as serology for hepatitis A, B, C, Epstein-Barr virus and cytomegalovirus, were negative. Computed tomography of the abdomen revealed two lymph nodes measuring $1 \mathrm{~cm}$ in the cardiophrenic and aortocaval regions, and multiple small periportal and ileocolic mesenteric lymph nodes. Biliary tract dilation and hepatic space-occupying lesions were excluded. A liver biopsy revealed mononuclear infiltration within the portal triads and perivenular areas, mild hepatocellular necrosis (Figure 1) and moderate interface hepatitis. Isolated eosinophils were present (Figure 2). Histologically, cholestasis was not evident. The bile ductular epithelium was normal and there was no fibrosis or evidence of a lymphoproliferative disorder.

A diagnosis of rofecoxib-induced cholestatic hepatitis was made. Rofecoxib was discontinued and ursodeoxycholic acid $1500 \mathrm{mg} /$ day was introduced. Within one month, the patient's bilirubin had fallen to $75 \mu \mathrm{mol} / \mathrm{L}$, ALP to $212 \mathrm{U} / \mathrm{L}$ and ALT to $893 \mathrm{U} / \mathrm{L}$. Within two months, the patient's liver biochemistry normalized and his symptoms resolved. Six months later, the patient was asymptomatic, had normal liver biochemistry and had received adjuvant radiotherapy for his lymphoma.

\section{Case 2}

A 44-year-old Asian woman presented with a two-week history of anorexia, fatigue, choluria, pruritus and jaundice. The patient became unwell 10 weeks before presentation when she developed migratory arthralgias affecting her wrists, shoulders, knees and toes with morning stiffness and joint redness. Associated symptoms included sore throat, fatigue, myalgias, a $3 \mathrm{~kg}$ weight loss and a fluctuating macular rash over her torso and thighs. She denied oral ulceration, facial rash, alopecia or other symptoms suggestive of connective tissue disease. Approximately eight weeks before presentation (two weeks into her illness), she started rofecoxib $12.5 \mathrm{mg}$ daily for arthralgia. Within two to three weeks, her arthralgia improved and she continued rofecoxib therapy.

The patient's medical history included asthma, multinodular goiter and beta-thalassemia trait. Her other medications included bronchodilators and an oral contraceptive which was long-standing. She denied ingestion of

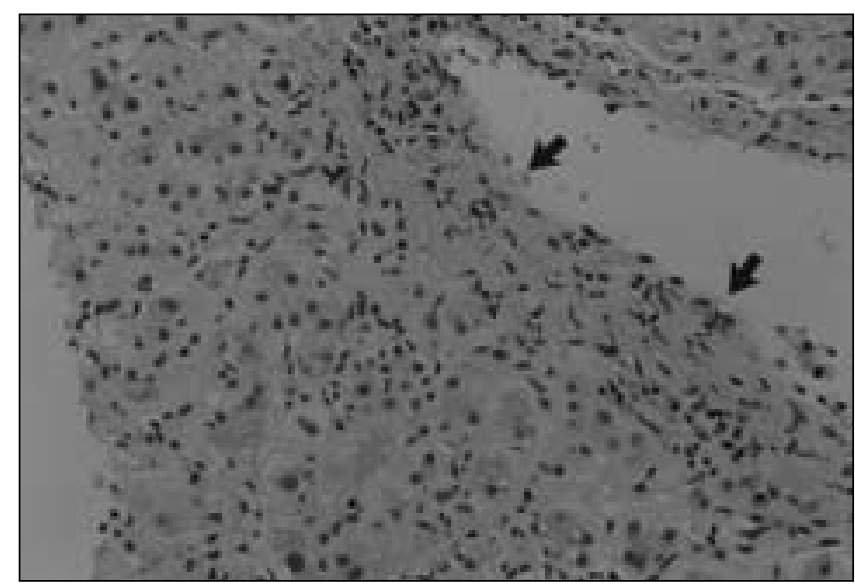

Figure 2) Perivenular inflammatory infiltrate composed of mononuclear cells and prominent eosinophils (arrows) (hematoxylin and eosin stain, original magnification $\times 200$ )

alcohol or other potential hepatotoxins. There was no family history of liver disease or risk factors for viral hepatitis.

On examination, the patient was jaundiced, but was afebrile and had no sign of chronic liver disease, organomegaly or abdominal tenderness. The thyroid was slightly enlarged and symmetrical with no palpable nodules. Musculoskeletal examination was normal. There was a diffuse, erythematous, macular rash on her face, arms, back and upper thighs. Laboratory investigations included mild microcytic anemia (hemoglobin $117 \mathrm{~g} / \mathrm{L}$; mean corpuscular volume $69 \mathrm{fL})$, but normal platelet and white blood cell counts. The liver biochemistry was as follows: ALT $995 \mathrm{U} / \mathrm{L}$; ALP $243 \mathrm{U} / \mathrm{L}$; gamma-glutamyltransferase $99 \mathrm{U} / \mathrm{L}$; total bilirubin $207 \mu \mathrm{mol} / \mathrm{L}$; albumin $27 \mathrm{~g} / \mathrm{L}$ and an international normalized ratio of 1.1. Serology for acute hepatitis A, B and C, and parvovirus B19 was negative. The ANA was positive (1:320 in a speckled pattern) but rheumatoid factor and antibodies to smooth muscle, mitochondria, liver/kidney microsome type I and extractable nuclear antigens (including Jo-1, ribonucleoprotein, Sclero-70, Sm, SS-A/Ro, SS-B/La and chromatin) were negative. Serum immunoglobulin (Ig) $\mathrm{G}$ was slightly elevated $(20.75 \mathrm{~g} / \mathrm{L}$; normal less than $18.0 \mathrm{~g} / \mathrm{L}$ ) but IgA, IgM and ceruloplasmin were normal. An abdominal ultrasound revealed an echogenic liver. Histologically, mild macrovesicular steatosis and established fibrosis of both portal and perivenular distribution was identified (Figure 3), suggestive of a chronic process. A mononuclear inflammatory infiltrate in a portal and lobular distribution was also observed (Figure 4). No eosinophils were present and the bile ducts were normal.

These findings were interpreted as indicative of an acute drug-induced hepatotoxicity superimposed on previously subclinical liver injury of uncertain etiology. Rofecoxib was discontinued and within one week her hepatic symptoms resolved. The liver biochemistry normalized over the ensuing month. The patient's liver profile remains normal and she is clinically well, although she has had intermittent rash and arthralgias of unclear etiology.

\section{DISCUSSION}

Due to their improved gastrointestinal safety profile, the coxibs have dominated the global market for prescription NSAIDs. Before its recent withdrawal by the manufacturer, approximately 


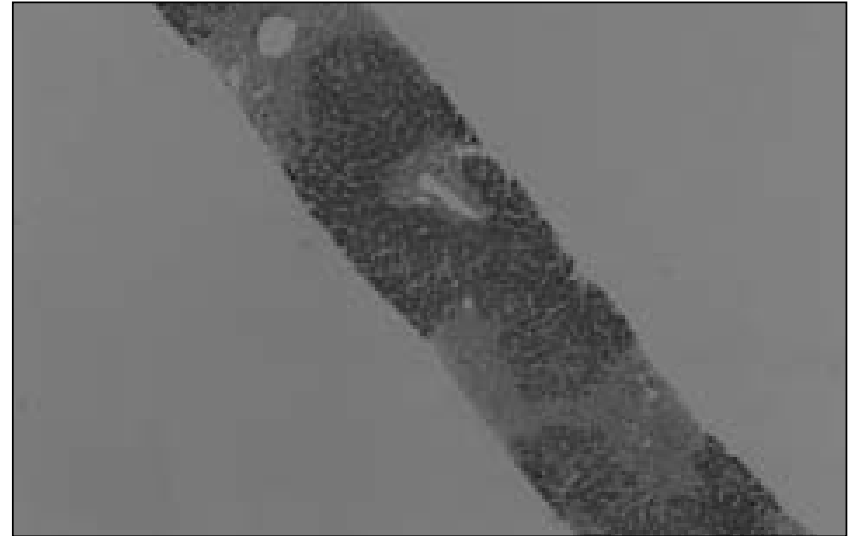

Figure 3) Established perivenular and periportal fibrosis associated with an inflammatory infiltrate and mild steatosis (periodic acid-Schiff stain, original magnification $\times 40$ )

80 million patients had received rofecoxib and annual sales exceeded $\$ 2.5$ billion (4). In the present report, we describe two cases of severe hepatotoxicity due to rofecoxib to highlight this potentially serious complication of the coxibs. Because another medication of this class (celecoxib) remains on the North American market, and others (etoricoxib and lumiracoxib) are awaiting approval, it is imperative that physicians recognize the potential for significant hepatic injury attributable to these medications.

Hepatotoxicity is a well-recognized, albeit uncommon, complication of NSAID therapy. Significant liver injury attributable to the coxibs is less frequent than with nonselective NSAIDs $(6,7)$. In the CLASS, an ALT elevation greater than three times the upper limit of normal was observed in $0.2 \%$ of celecoxib-treated patients compared with $1.7 \%$ of those receiving diclofenac or ibuprofen (3). In a review of 14 controlled trials (8), the frequency of hepatic dysfunction was not significantly different between celecoxib $(0.8 \%)$ and placebo $(0.9 \%)$. In clinical trials of rofecoxib and valdecoxib, $0.3 \%$ to $0.5 \%$ of patients experienced significant ALT elevations but no cases of severe hepatotoxicity were reported $(9,10)$. However, since the approval of the coxibs, 11 other cases of severe hepatic injury have been reported in the English literature (four with rofecoxib [11-14], seven with celecoxib [15-21] and none with valdecoxib). This finding emphasizes the critical role of postmarketing surveillance in detecting these rare but serious adverse events that may escape detection in preclinical testing.

We are confident that a causal relationship exists between rofecoxib therapy and liver dysfunction in the cases described $(22,23)$. Both cases were highly probable of drug-induced liver injury according to the Council for International Organizations of Medical Sciences scale for causality assessment in drug hepatotoxicity $(24,25)$. The temporal association was appropriate (symptoms within two to six weeks of drug initiation) and clinical and biochemical improvements were observed rapidly upon rofecoxib discontinuation. Moreover, we were careful to exclude other causes of liver injury including viral hepatitis, hepatotoxicity due to other toxins and autoimmune hepatitis. In this regard, our first patient had previously received rofexocib on several brief occasions without apparent hepatotoxicity. We speculate that the patient was sensitized to

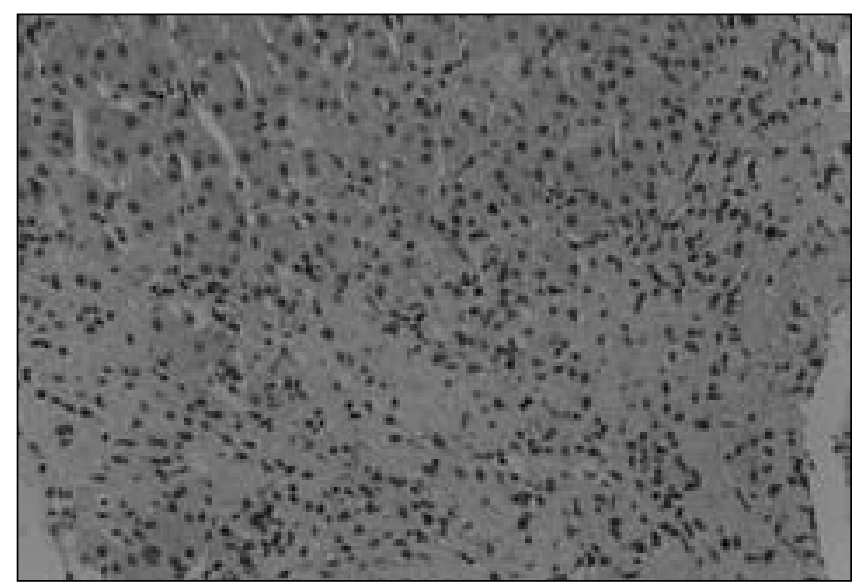

Figure 4) Area of perivenular fibrosis uniformly inflamed with mononuclear cells without eosinophils (hematoxylin and eosin stain, original magnification $\times 200$ )

rofecoxib by repeated use and hepatotoxicity only became apparent on prolonged exposure.

Our second patient was prescribed rofecoxib for arthritic symptoms in association with a rash, sore throat, fatigue, myalgias, weight loss and ANA positivity. One might argue that the acute hepatitis in this patient was attributable to a nonhepatotrophic viral infection, autoimmune hepatitis or a systemic inflammatory disorder. Although possible, the histological findings and abrupt improvement with rofecoxib discontinuation were more consistent with drug toxicity. Moreover, the patient has continued to have intermittent arthralgias and rash despite the absence of hepatic symptoms or abnormal liver biochemistry. We speculate that she has an undefined connective tissue disorder that is unrelated to her acute hepatitis. Nonhepatotrophic viruses (eg, parvovirus B19, Epstein-Barr virus, cytomegalovirus and human herpesvirus-6) may cause a similar constellation of symptoms and a role has been proposed in the promotion of drug-induced hypersensitivity $(26,27)$. We excluded parvovirus B19 infection in this case, but cannot definitively discount infection with another virus, either as the sole explanation for her symptoms or as a predisposing factor for drug-related hepatotoxicity. Interestingly, established fibrosis was demonstrated histologically in this patient, suggesting a pre-existing liver disorder. Although lacking metabolic risk factors for nonalcoholic fatty liver disease (NAFLD), this diagnosis would be supported by the histological findings of macrovesicular steatosis, hepatic echogenicity on ultrasound and ANA positivity (seen in approximately one-third of NAFLD patients) (28). Whether underlying NAFLD may have predisposed to rofecoxib-induced hepatoxicity in this patient, as reported in other causes of drug-induced liver injury (eg, methotrexate), is unclear (29).

The two cases described in the present report illustrate the variability in presentation of rofecoxib-induced hepatic injury. Although both patients had cholestatic symptoms, their liver biochemistry and histology differed substantially. The first patient presented with a biochemical pattern of mixed hepatocellular and cholestatic injury (ie, cholestatic hepatitis). A liver biopsy demonstrated predominantly zone 1 injury with hepatocellular damage. On the other hand, the second patient had a significant ALT elevation (with only a minimal rise in ALP 


\section{TABLE 1}

Clinical characteristics of six patients with severe rofecoxib-induced hepatotoxicity

\begin{tabular}{|c|c|c|c|c|c|c|}
\hline $\begin{array}{l}\text { Reference, } \\
\text { year }\end{array}$ & $\begin{array}{c}\text { Patient } \\
\text { (age/sex) }\end{array}$ & $\begin{array}{l}\text { Dose and } \\
\text { duration }\end{array}$ & Symptoms & $\begin{array}{c}\text { Liver } \\
\text { biochemistry* }\end{array}$ & Liver histology & $\begin{array}{c}\text { Normalization of liver } \\
\text { enzymes (treatment) }\end{array}$ \\
\hline $\begin{array}{l}\text { Huster et al (11) } \\
2002\end{array}$ & $52 \mathrm{~F}$ & $\begin{array}{l}25 \mathrm{mg} / \text { day } \\
3 \text { months }\end{array}$ & Jaundice, pruritus, malaise & $\begin{array}{l}\text { ALT } 228 \mathrm{U} / \mathrm{L} \\
\text { ALP } 1314 \mathrm{U} / \mathrm{L} \\
\text { Bili } 420 \mu \mathrm{mol} / \mathrm{L}\end{array}$ & $\begin{array}{l}\text { Hepatocellular/canalicular cholestasis } \\
\text { Portal inflammation (eosinophils) }\end{array}$ & $\begin{array}{l}2.5 \text { months } \\
\text { (MARS and UDCA ) }\end{array}$ \\
\hline $\begin{array}{l}\text { Harsch et al (12) } \\
2003\end{array}$ & $73 \mathrm{~F}$ & $\begin{array}{c}25 \mathrm{mg} / \text { day } \\
10 \text { days }\end{array}$ & Jaundice & $\begin{array}{l}\text { ALT } 440 \mathrm{U} / \mathrm{L} \\
\text { ALP } 435 \mathrm{U} / \mathrm{L} \\
\text { Bili } 170 \mu \mathrm{mol} / \mathrm{L}\end{array}$ & $\begin{array}{l}\text { Hepatocellular/canalicular cholestasis } \\
\text { Portal inflammation (lymphocytes } \\
\text { and eosinophils) } \\
\text { Bile duct destruction } \\
\text { Focal hepatocyte necrosis }\end{array}$ & 2 months \\
\hline $\begin{array}{l}\text { Papachristou et al (14) } \\
2004\end{array}$ & $76 \mathrm{~F}$ & $\begin{array}{l}25 \mathrm{mg} / \mathrm{day} \\
22 \text { months }\end{array}$ & $\begin{array}{l}\text { Jaundice, pruritus, } \\
\text { choluria, acholic stool }\end{array}$ & $\begin{array}{l}\text { ALT } 239 \mathrm{U} / \mathrm{L} \\
\text { ALP } 314 \mathrm{U} / \mathrm{L} \\
\text { Bili } 95 \mu \mathrm{mol} / \mathrm{L}\end{array}$ & $\begin{array}{l}\text { Hepatocellular/canalicular cholestasis } \\
\text { Portal inflammation (lymphocytes) } \\
\text { Bile duct destruction }\end{array}$ & 3 months (UDCA) \\
\hline $\begin{array}{l}\text { Linares et al (13) } \\
2004\end{array}$ & $74 \mathrm{~F}$ & $\begin{array}{l}12.5 \mathrm{mg} / \mathrm{day} \\
2 \text { months }\end{array}$ & $\begin{array}{l}\text { Jaundice, fatigue, vomiting, } \\
\text { choluria, bloody } \\
\text { diarrhea, renal failure }\end{array}$ & $\begin{array}{l}\text { ALT } 31 \mathrm{U} / \mathrm{L} \\
\text { ALP } 2968 \mathrm{U} / \mathrm{L} \\
\text { Bili } 205 \mu \mathrm{mol} / \mathrm{L}\end{array}$ & Centrilobular cholestasis & $\begin{array}{c}>2 \text { years }^{\dagger} \\
\text { (UDCA and prednisone) }\end{array}$ \\
\hline $\begin{array}{l}\text { Yan et al (present study) } \\
2006 \text { (case 2) }\end{array}$ & ) $44 \mathrm{~F}$ & $\begin{array}{l}12.5 \mathrm{mg} / \mathrm{day} \\
8 \text { weeks }\end{array}$ & $\begin{array}{l}\text { Jaundice, pruritus, } \\
\text { choluria, fatigue, } \\
\text { anorexia }\end{array}$ & $\begin{array}{l}\text { ALT } 995 \mathrm{U} / \mathrm{L} \\
\text { ALP } 243 \mathrm{U} / \mathrm{L} \\
\text { Bili } 207 \mu \mathrm{mol} / \mathrm{L}\end{array}$ & $\begin{array}{l}\text { Mild portal and lobular } \\
\text { inflammation (lymphocytes) } \\
\text { Mild macrovesicular steatosis } \\
\text { Portal and perivenular fibrosis }\end{array}$ & 1 month \\
\hline
\end{tabular}

${ }^{*}$ Different reference ranges among laboratories where bilirubin was reported in $\mathrm{mg} / \mathrm{dL}$, conversion made $u$ sing $1 \mathrm{mg} / \mathrm{dL}=17.1 \mu \mathrm{mol} / \mathrm{L} ;{ }^{\dagger} \mathrm{Mild}$ abnormalities of alkaline phosphatase (ALP) and gamma-glutamyltransferase persist after more than two years, vanishing bile duct syndrome is suspected but not histologically proven. ALT Alanine aminotransferase; Bili Total bilirubin; F Female; M Male; MARS Molecular adsorbent recycling system; UDCA Ursodeoxycholic acid

levels) and a liver biopsy demonstrating mild zone 1 and zone 3 injury. In the four previously reported cases of rofecoxib-induced hepatotoxicity (11-14), the clinical presentations were primarily cholestatic (Table 1), although cases of predominantly hepatocellular injury have been reported with celecoxib $(15,17,18)$.

Our cases also appeared to differ in their speed of resolution following dechallenge. As observed commonly in drug-induced hepatotoxicity, complete biochemical normalization was slower in our patient with cholestatic hepatitis $(24,25)$. This patient has not developed a vanishing bile duct syndrome, although this complication is suspected in a case with persistently cholestatic liver enzymes more than two years following discontinuation of rofecoxib (13). None of the patients described in the literature developed evidence of acute liver failure perhaps due to rapid withdrawal of the offending medication. With the exception of bromfenac, which was recently withdrawn from the market due to hepatotoxicity, acute liver failure appears to be an uncommon complication of NSAIDs (30). Finally, none of our patients demonstrated signs of a hypersensitivity reaction (eg, fever, rash and eosinophilia) attributable to rofecoxib therapy. Hypersensitivity has been reported in the setting of celecoxibinduced hepatotoxity; however, this patient was allergic to sulfonamides, a known contraindication to celecoxib (16).

Management of coxib-induced hepatic injury is empirical, but consists of drug withdrawal and supportive therapy. Corticosteroids (13) and ursodeoxycholic acid $(11,13,14)$ have been used (including in one of our patients) but their efficacy is unclear in the absence of controlled data. In one case (11), extracorporeal albumin dialysis (molecular adsorbent recycling system) appeared beneficial for cholestasis resistant to conventional therapy.

To our knowledge, the molecular mechanisms underlying coxib-induced hepatic injury have not been established. In contrast, the etiology of hepatotoxicity attributable to nonselective NSAIDs has been extensively investigated (7). Experimental evidence suggests that at least three mechanisms likely play a role:

- mitochondrial injury (31);

- induction of cholestasis (eg, via competition for hepatobiliary transmembrane transporters) (32,33); and

- formation of reactive metabolites that covalently modify proteins and produce oxidative stress (33).

Genetic and/or acquired patient factors may contribute to hepatotoxicity by either augmenting the pathways leading to hepatic toxicity or impeding protective and detoxifying pathways (7). For example, a potential role of polymorphisms in human UDP-glucuronosyltransferases (UG2B7 and UG2B15) responsible for rofecoxib metabolism (34) has been proposed but not investigated (12). Moreover, recent evidence suggests that COX-2 inhibition by NSAIDs may play a role in liver injury through effects on prostaglandins (PGs), notably $\mathrm{PGE}_{2}$. Inhibition of $\mathrm{PGE}_{2}$ may downregulate the antiapoptotic mitochondrial protein $\mathrm{Bcl}-2$, which protects against bile acidinduced apoptosis (35). Indeed, a recent study (36) of a murine model of acetaminophen-induced hepatotoxicity demonstrated increased susceptibility to liver injury in COX-2-deficient mice, 
an effect that was reproduced by celecoxib treatment in wildtype mice. It appears that this effect is mediated by a reduction in $\mathrm{PGE}_{2}$ and $\mathrm{PGD}_{2}$ in $\mathrm{COX}$-2-deficient mice that leads to an impairment in the ability to induce expression of hepatoprotective heat shock proteins.

Hepatotoxicity is a potentially serious, but uncommon, complication of coxib therapy. Although rofecoxib has now been withdrawn from the market, previous cases of hepatic

\section{REFERENCES}

1. FitzGerald GA, Patrono C. The coxibs, selective inhibitors of cyclooxygenase-2. N Engl J Med 2001;345:433-42.

2. Bombardier C, Laine L, Reicin A, et al. Comparison of upper gastrointestinal toxicity of rofecoxib and naproxen in patients with rheumatoid arthritis. VIGOR Study Group. N Engl J Med 2000;343:1520-8.

3. Silverstein FE, Faich G, Goldstein JL, et al. Gastrointestinal toxicity with celecoxib vs nonsteroidal anti-inflammatory drugs for osteoarthritis and rheumatoid arthritis: the CLASS study: A randomized controlled trial. Celecoxib Long-term Arthritis Safety Study. JAMA 2000;284:1247-55.

4. Fitzgerald GA. Coxibs and cardiovascular disease. N Engl J Med 2004;351:1709-11.

5. Topol EJ. Failing the public health-rofecoxib, Merck, and the FDA. N Engl J Med 2004;351:1707-9.

6. Teoh NC, Farrell GC. Hepatotoxicity associated with nonsteroidal anti-inflammatory drugs. Clin Liver Dis 2003;7:401-13.

7. Boelsterli UA. Mechanisms of NSAID-induced hepatotoxicity: Focus on nimesulide. Drug Saf 2002;25:633-48.

8. Maddrey WC, Maurath CJ, Verburg KM, Geis GS. The hepatic safety and tolerability of the novel cyclooxygenase-2 inhibitor celecoxib. Am J Ther 2000;7:153-8.

9. Bextra (Valdecoxib) Product Monograph. In: Repchinsky C, ed. Compendium of Pharmaceuticals and Specialties. The Canadian Drug Reference for Health Professionals. Ottawa, Ontario: Canadian Pharmacists Association, 2004:271-6.

10. Vioxx (Rofecoxib) Product Monograph. In: Repchinsky C, ed. Compendium of Pharmaceuticals and Specialties. The Canadian Drug Reference for Health Professionals. Ottawa, Ontario: Canadian Pharmacists Association, 2004:2173-8.

11. Huster D, Schubert C, Berr F, Mossner J, Caca K. Rofecoxib-induced cholestatic hepatitis: Treatment with molecular adsorbent recycling system (MARS). J Hepatol 2002;37:413-4.

12. Harsch IA, Michaeli P, Hahn EG, Konturek PC, Klein R. A rare case of rofecoxib-induced cholestatic hepatitis. Dig Liver Dis 2003;35:911-2

13. Linares P, Vivas S, Jorquera F, Olcoz JL, de Leon B, Oritz de Urbina J. Severe cholestasis and acute renal failure related to rofecoxib. Am J Gastroenterol 2004;99:1622-3.

14. Papachristou GI, Demetris AJ, Rabinovitz M. Acute cholestatic hepatitis associated with long-term use of rofecoxib. Dig Dis Sci 2004:49:459-61.

15. Carrillo-Jimenez R, Nurnberger M. Celecoxib-induced acute pancreatitis and hepatitis: A case report. Arch Intern Med 2000;160:553-4

16. Galan MV, Gordon SC, Silverman AL. Celecoxib-induced cholestatic hepatitis. Ann Intern Med 2001;134:254.

17. Nachimuthu S, Volfinzon L, Gopal L. Acute hepatocellular and cholestatic injury in a patient taking celecoxib. Postgrad Med J 2001;77:548-50.

18. O'Beirne JP, Cairns SR. Drug Points: Cholestatic hepatitis in association with celecoxib. BMJ 2001;323:23.

19. Alegria P, Lebre L, Chagas C. Celecoxib-induced cholestatic hepatotoxicity in a patient with cirrhosis. Ann Intern Med 2002;137:75. injury attributable to celecoxib suggest that this may be a class effect. With new coxibs and expanding indications on the horizon (eg, chemoprevention of cancer [37]), physicians in all areas of practice must be aware of this disorder and consider it in any patient who develops hepatic dysfunction after taking a coxib. Management consists of immediate withdrawal of the coxib and supportive therapy.

20. Grieco A, Miele L, Giorgi A, Civello IM, Gasbarrini G. Acute cholestatic hepatitis associated with celecoxib. Ann Pharmacother 2002;36:1887-9.

21. Zinsser P, Meyer-Wyss B, Rich P. Hepatotoxicity induced by celecoxib and amlodipine. Swiss Med Wkly 2004;134:201.

22. Kaplowitz N. Causality assessment versus guilt-by-association in drug hepatotoxicity. Hepatology 2001;33:308-10.

23. Lee WM. Assessing causality in drug-induced liver injury. J Hepatol 2000;33:1003-5.

24. Danan G, Benichou C. Causality assessment of adverse reactions to drugs - I. A novel method based on the conclusions of international consensus meetings: Application to drug-induced liver injuries. J Clin Epidemiol 1993;46:1323-30.

25. Benichou C, Danan G, Flahault A. Causality assessment of adverse reactions to drugs - II. An original model for validation of drug causality assessment methods: Case reports with positive rechallenge. J Clin Epidemiol 1993;46:1331-6.

26. Suzuki Y, Inagi R, Aono T, Yamanishi K, Shiohara T. Human herpesvirus 6 infection as a risk factor for the development of severe drug-induced hypersensitivity syndrome. Arch Dermatol 1998;134:1108-12.

27. Regnier S, Descamps V, Boui M, et al. Parvovirus B19 infection mimicking drug-induced hypersensitivity syndrome. Ann Dermatol Venereol 2000;127:505-6.

28. Neuschwander-Tetri BA, Caldwell SH. Nonalcoholic steatohepatitis: Summary of an AASLD Single Topic Conference. Hepatology 2003;37:1202-19.

29. Farrell GC. Drugs and steatohepatitis. Semin Liver Dis 2002;22:185-94.

30. Schiodt FV, Lee WM. Fulminant liver disease. Clin Liver Dis 2003; 7:331-49.

31. Browne GS, Nelson C, Nguyen T, Ellis BA, Day RO, Williams KM. Stereoselective and substrate-dependent inhibition of hepatic mitochondria beta-oxidation and oxidative phosphorylation by the nonsteroidal anti-inflammatory drugs ibuprofen, flurbiprofen, and ketorolac. Biochem Pharmacol 1999;57:837-44.

32. Bolder U, Trang NV, Hagey LR, et al. Sulindac is excreted into bile by a canalicular bile salt pump and undergoes a cholehepatic circulation in rats. Gastroenterology 1999;117:962-71.

33. Seitz S, Kretz-Rommel A, Oude Elferink RP, Boelsterli UA. Selective protein adduct formation of diclofenac glucuronide is critically dependent on the rat canalicular conjugate export pump (Mrp2). Chem Res Toxicol 1998;11:513-9.

34. Zhang JY, Zhan J, Cook CS, Ings RM, Breau AP. Involvement of human UGT2B7 and 2B15 in rofecoxib metabolism. Drug Metab Dispos 2003;31:652-8.

35. Souto EO, Miyoshi H, Dubois RN, Gores GJ. Kupffer cell-derived cyclooxygenase- 2 regulates hepatocyte $\mathrm{Bcl}-2$ expression in choledochovenous fistula rats. Am J Physiol Gastrointest Liver Physiol 2001;280:G805-11.

36. Reilly TP, Brady JN, Marchick MR, et al. A protective role for cyclooxygenase-2 in drug-induced liver injury in mice. Chem Res Toxicol 2001;14:1620-8.

37. Reddy BS, Hirose Y, Lubet R, et al. Chemoprevention of colon cancer by specific cyclooxygenase-2 inhibitor, celecoxib, administered during different stages of carcinogenesis. Cancer Res 2000;60:293-7. 


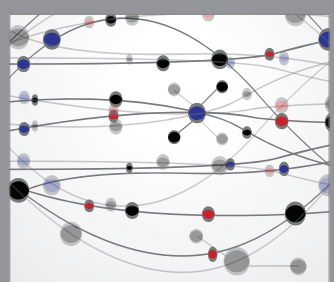

The Scientific World Journal
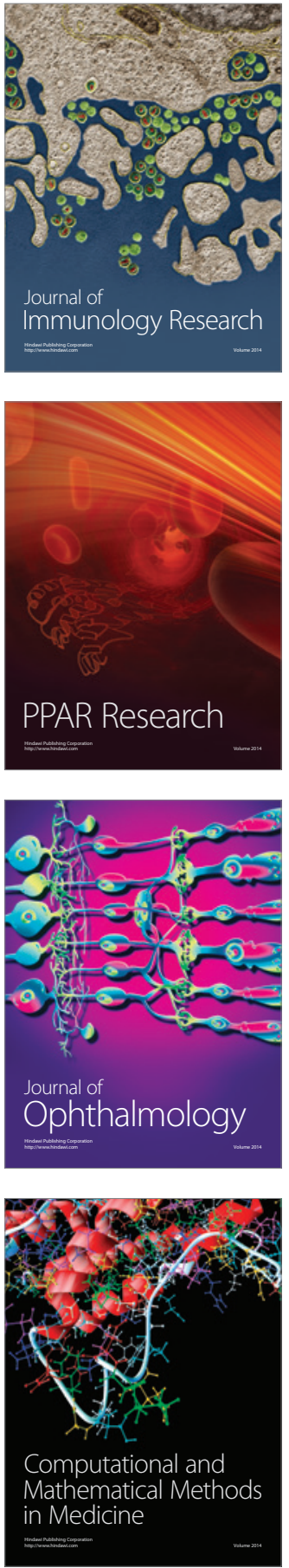

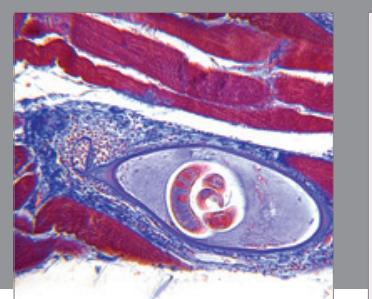

Gastroenterology Research and Practice

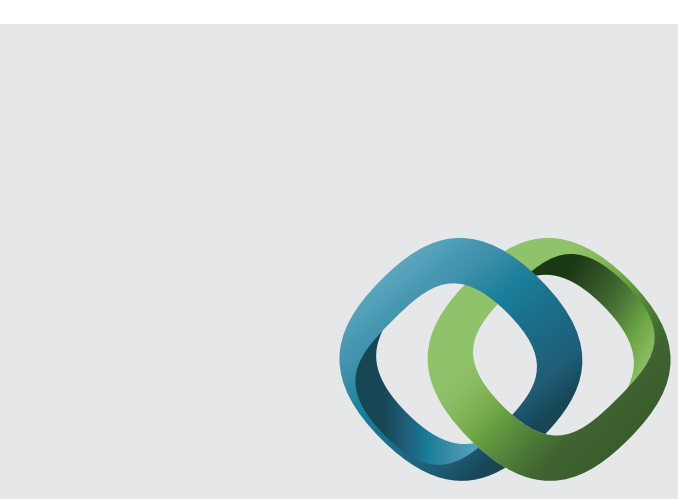

\section{Hindawi}

Submit your manuscripts at

http://www.hindawi.com
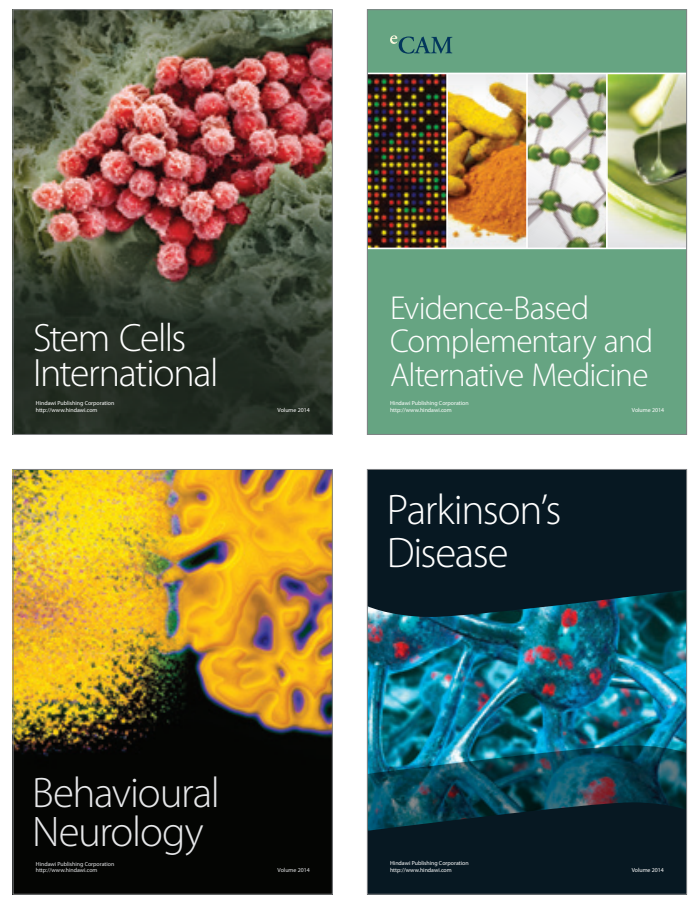
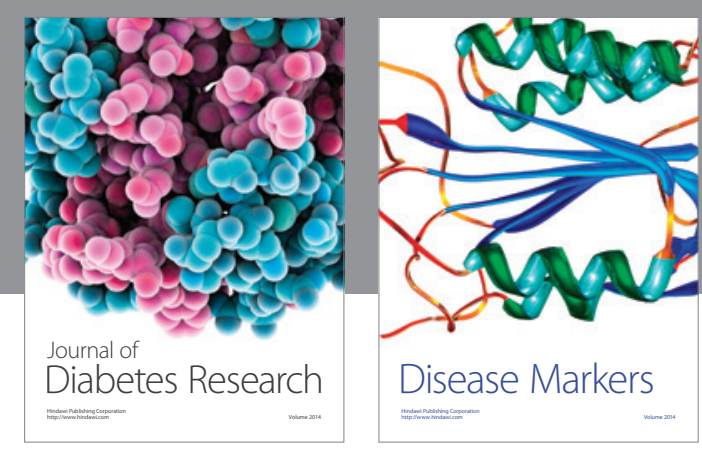

Disease Markers
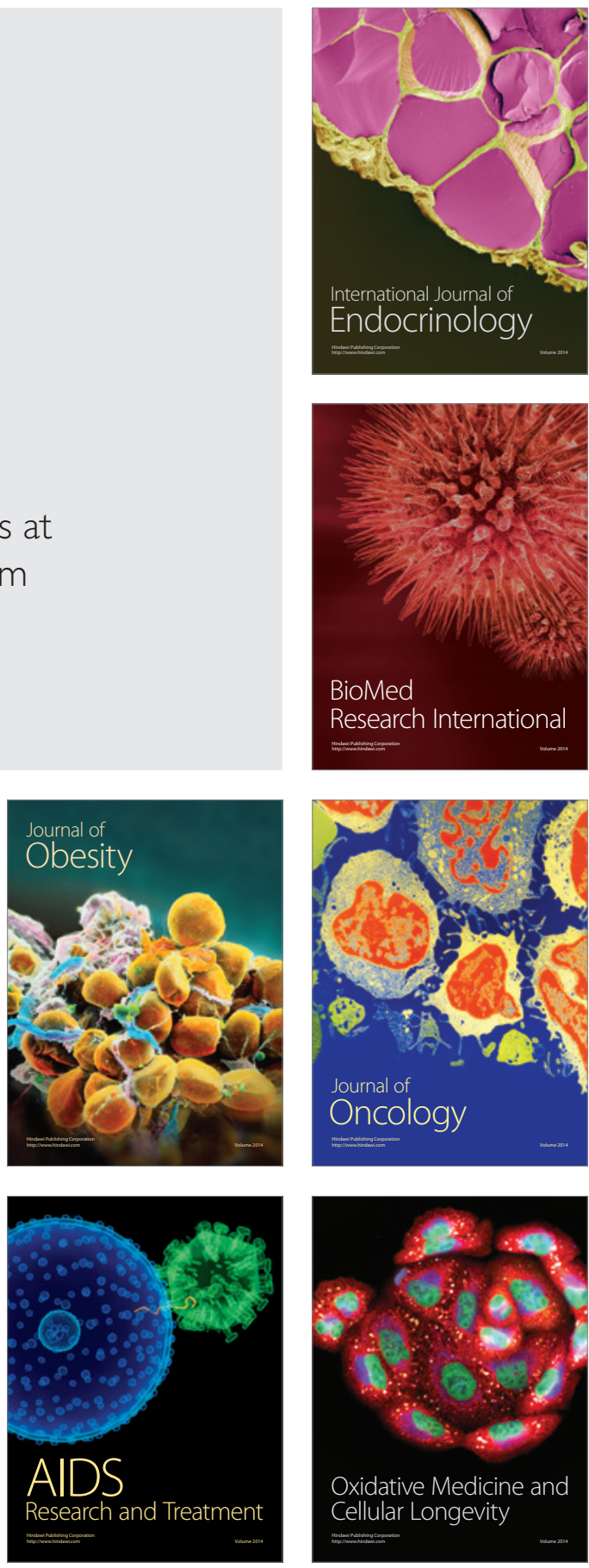